African Crop Science Journal by African Crop Science Society is licensed under a Creative Commons Attribution 3.0 Uganda License. Based on a work at www.ajol.info/ and www.bioline.org.br/cs DOI: https://dx.doi.org/10.4314/acsj.v27i2.13

\title{
DISTRIBUTION OF COMMON BACTERIAL BLIGHT DISEASE UNDER DIFFERENT AGROECOLOGIES IN UGANDA
}

\section{J.K. TUGUME ${ }^{12}$, G. TUSIIME ${ }^{2}$, P. WASWA ${ }^{2}$, C.M. MUKANKUSI ${ }^{1}$ and R. BURUCHARA ${ }^{1}$}

${ }^{2}$ Makerere University, Department of Agricultural Production. P. O. Box 7062, Kampala, Uganda 'International Centre for Tropical Agriculture (CIAT)/Pan African Bean Research Alliance (PABRA), P. O. Box 6247 , Kampala, Uganda

Corresponding author: tugume2006@yahoo.com

(Received 22 March 2018; accepted 8 May 2019)

\begin{abstract}
Common bacterial blight disease (CBB) causes severe yield and seed quality losses on common bean worldwide. Information about CBB distribution is important in designing effective control strategies. This disease has been managed using intergraded strategies, involving use of certified seed produced in areas of low disease pressure. Unfortunately, areas of low CBB pressure have not been mapped in Uganda. This study was conducted to determine the distribution and intensity of CBB in Uganda, in order to establish low pressure areas for multiplication of clean certified seed. A survey was conducted in farmers' fields in 18 locations found in four rainfalls-based agroecology in Uganda, for two seasons of 2016. The Victoria Cresent and Mbale farmland had the highest disease intensity index (29\%); followed by Central woodland savannah (21\%). The Northwest farm land and South west grass farm lands had low CBB intensity index of 2.5 and $7.8 \%$, respectively. Thus, The Northwest farm land (Arua, Amuru, Nwoya) and South west grass farm lands (Rakai, Ntungamo Lwengo and Bukomansimbi), are recommended for production of CBB free bean seeds.
\end{abstract}

Key Words: Integrated, intensity, Lake Victoria Cresent

\section{RÉSUMÉ}

La maladie bactérienne commune (MBC) provoque de graves pertes de rendement et de qualité des semences de haricot commun dans le monde entier. Les informations sur la distribution du MBC sont importantes pour la conception de stratégies de contrôle efficaces. Cette maladie a été gérée à l'aide de stratégies intercalées, impliquant l'utilisation de semences certifiées produites dans des zones de faible pression de la maladie. Malheureusement, les zones de faible pression du CBB n'ont pas été cartographiées en Ouganda. Cette étude a été faite pour déterminer la distribution et l'intensité du CBB en Ouganda, afin d'établir des zones de basse pression pour la multiplication de semences certifies qui sont propres. Une enquête a été faite dans les champs d'agriculteurs dans 18 localités situées dans quatre agroécologies en Ouganda basées sur les précipitations, pendant les deux saisons de 2016. Les terres agricoles de Victoria Cresent et de Mbale présentaient l'indice d'intensité de 
maladie le plus élevé (29\%); suivi de la savane boisée centrale (21\%). Les terres agricoles du nordouest et celles du sud-ouest avaient un indice d'intensité de CBB faible de 2,5 et 7,8\%, respectivement. Ainsi, les terres agricoles du Nord-Ouest (Arua, Amuru, Nwoya) et celles du Sud-Ouest (Rakai, Ntungamo Lwengo et Bukomansimbi) sont recommandées pour la production de semences de haricot exemptes de CBB.

Mots Clés: Intégré, intensité, Lac Victoria cescent

\section{INTRODUCTION}

Common bean (Phaseolus vulgaris) is a major food legume grown worldwide. It is an important crop in the entire Great Lakes Region of Africa (Buruchara et al., 2011). Common bacterial blight disease (CBB) is a major cause of severe common bean yield and seed quality losses ranging between $200-1000 \mathrm{~kg} \mathrm{ha}^{-1}$ depending on cultivar and location (CIAT, 2014). In Uganda, Common bacterial blight disease contributes to the low productivity estimated at $1.5 \mathrm{t} \mathrm{ha}^{-1}$, which is less by $30 \%$ of the potential yield (UCA, 2009). CBB disease is mainly spread through seed and in the field by rain splash (Opio et al., 1996; Karavina et al., 2011). Management options are mainly cultural involving use of disease-free seed, field sanitation and crop rotation (Opio et al., 1996; Karavina, et al., 2011).

Farmers, especially in Uganda, commonly use home saved seed or purchase bean grain from the market for planting. The planted bean grain from the market is normally of unknown source and health status. Bean grain trade markets are, thus thought to aid the movement and distribution of CBB disease pathogens to new areas, changing the pathogen diversity, distribution and consequently disease pressure in areas of introduction. It is, thus possible that the distribution of $\mathrm{CBB}$ disease and its causal pathogen in Uganda could be different from what was earlier reported by Wortman et al. (1998) due to either new introduction or climatic change. The aim of this research was to determine low $\mathrm{CBB}$ disease pressure locations in Uganda for production and multiplication of $\mathrm{CBB}$ free seeds for distribution in the country.

\section{METHODOLOGY}

A survey of farmers' fields in Uganda was conducted in the first and second seasons of 2016 to determine the incidence, severity and spread of CBB. The survey was done in 370 fields selected from 18 districts (Kisoro, Kabale, Ntungamo, Rakai, Lwengo, Masaka, Bukomansimbi, Luwero, Mubende, Mbale, Bulambuli, Lira, Dokolo, Apac, Otuke, Nwoya, Amuru and Arua) some of which are major bean production areas of Uganda. The selected fields were located in low altitude (1000-1200 masl), mid altitude (1200-1500 masl) and high altitude $(>1500)$. The surveyed fields were located in different rainfall based agroecologies of Northwest farm land (NWF) $2.0 \mathrm{~N}-3.5 \mathrm{~N}$, Northern moist farm land (NMF) $1.5 \mathrm{~N}-3.0 \mathrm{~N}$, Central woodland savannah (CWS) $0.5 \mathrm{~S}-1.5 \mathrm{~N}$, Victoria Cresent and Mbale farm land (VC and MF), South west grass farm land (SWGF) $1.0 \mathrm{~S}-1.5 \mathrm{~N}$, Elgon Farm land (EF) $0.7 \mathrm{~N}-1.4 \mathrm{~N}$, South west high land $(\mathrm{SW}) 1.0 \mathrm{~S}-1.5 \mathrm{~S}$.

The fields of variable sizes ranging from 0.125-3 acres were surveyed at pre-flowering, during flowering, or at early seed set depending on the planting date across the two seasons. The survey was done from May-June 2016 for first season; and September- October 2016 for the second season. Both climbing and bush types were sampled, though the bush type was predominant. In each bean field, regardless of the variety planted, disease assessment was done by choosing three sites of the field, 10 $\mathrm{m}$ apart taken through a transect walk along the diagonal of the field. At each location in the field, 20 plants were randomly selected and assessed for disease incidence and severity. 
Incidence was assessed by dividing number of plants showing symptoms by the number sampled at each location and expressed as a percentage. Disease severity was rated using a visual scale of 1-5 according to BenjaranoAlcazar et al. (1996); where 1= No symptoms, $2=1-30 \%$ foliage affected, $3=30-65 \%$ foliage affected, $4=66-100 \%$ foliage affected, and 5 $=$ Dead plant. Since CBB is mainly spread through seed (Opio et al, 1993), the type and source of seed planted in farmers' fields were surveyed. Farmers were interviewed on the source of seed used for planting and the destination of their bean produce using a semistructured questionnaire.

Common blight bacteria disease incidence data were analysed using John Tukey's boxplot analysis to determine the variations in incidences in the surveyed regions. Disease intensity index for each surveyed locality was computed according to Benjarano-Alcazar et al. (1996). Incidence and severity values of foliage symptoms were used to calculate the disease intensity index $\left(D_{I}\right)$ that ranges from 0 to $100 \%$ using:

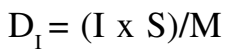

Where:

$\mathrm{I}=$ mean disease incidence $(\%), \mathrm{S}=$ mean disease severity score of foliar symptoms in diseased plants; and $\mathrm{M}=$ Maximum severity value (i.e., 5). The computed disease intensity indices of the surveyed localities were averaged over two seasons and mapped to rainfall map of Basalirwa et al. (1995) in order to add a spatial dimension to the disease data.

Disease intensity indices were compared to bean productivity of the surveyed localities obtained from secondary data of Uganda Census on Agriculture (UCA), 2009. Yield loses due to CBB were estimated from disease intensities according to Opio et al. (1992) with modifications by using disease intensities instead of incidence alone. Yield loss of 11.5 $\mathrm{kg} \mathrm{ha}^{-1}$ was estimated from $1 \%$ disease intensity.

\section{RESULTS}

Distribution of common bacterial blight disease. Common bacterial blight symptoms were observed in all agro-ecologies (Northwest farm land (NWF), Northern moist farm land (NMF), Central woodland savannah (CWS), Victoria Crescent and Mbale farm land (VC and MF), South west grass farm land (SWGF), Elgon Farm land (EF) and South West high land (SW). Common bacterial symptoms were observed on both climbing and bush bean types. The average CBB incidence across all agro-ecologies was $23.5 \%$ in first season and $15.5 \%$ in second season, and ranged from 0 $90 \%$ in the northern moist farmland, $0-60 \%$, in Central woodland savanah, $0-50 \%$ in Elgon farmland, 0-50\% in South west green grass. About $50 \%$ of the surveyed fields had incidences below $20 \%$.

The blight symptoms were variable, ranging from single spots to multiples spots, severe edge necrosis and severe necrosis (Plate 1A D). Based on the agro-ecology, the Victoria Cresent and Mbale farmland had the highest disease intensity (29\%); followed by Central woodland savannah $(21 \%)$. The Northwest farm land and South west grass farm lands had low CBB intensity index of 2.5 and $7.8 \%$, respectively (Table 1 ). In some cases, fields with high disease incidences were found in close proximity with fields of low disease incidence in Sisiyi and Mudwale subcounties of Bulambuli and Mbale in the Elgon farm land agro-ecology. The higher disease intensities between 21 and $44 \%$ were recorded in areas receiving $1000-1200 \mathrm{~mm}$ of rainfall annually. Traditionally wet areas like Nwoya and Amuru (1200-1570 mm) recorded extremely low common bacterial blight disease intensity index. Dry areas such as Rakai, Ntungamo, Arua, Lwengo and Bukomansimbi had low disease intensities (Table 2 and Fig. 1). 


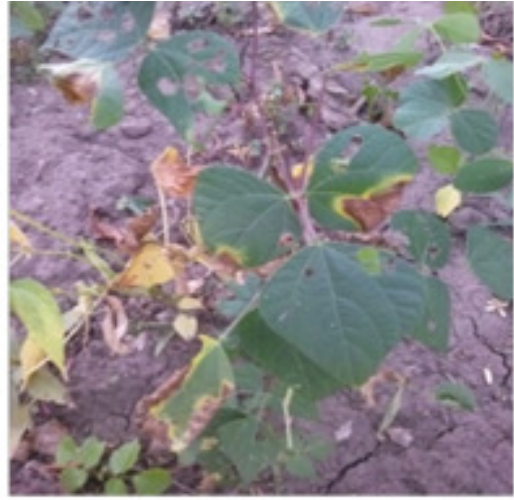

A

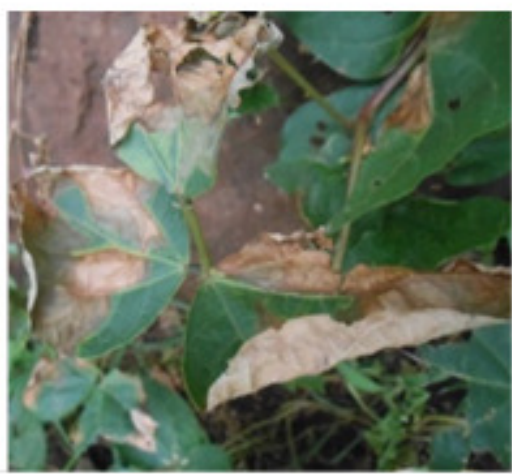

C

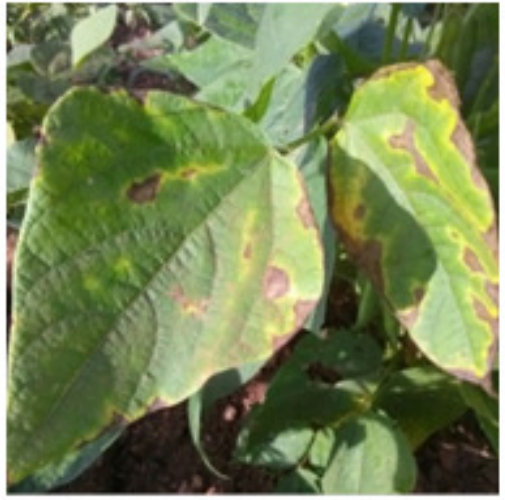

B

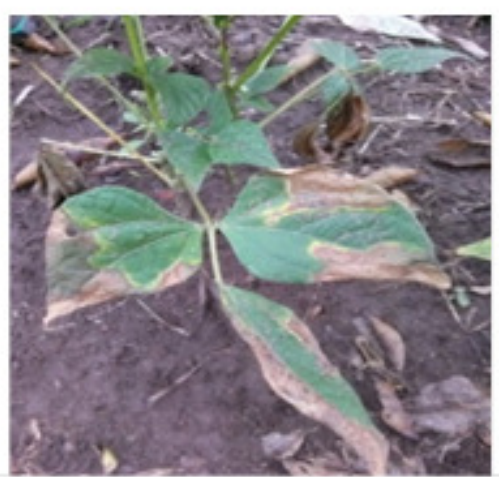

$\mathrm{D}$

Plate 1. Variation in CBB Symptom expression in the field; (A) Single spot, (B) Multiple spots, (C) Severe edge necrosis, (D) Typical CBB symptoms.

TABLE 1. Intensity of common bacterial blight in Agro-ecologies of Uganda as of 2016a

\begin{tabular}{llr}
\hline Agro-ecology & Representative districts & $\begin{array}{r}\text { Disease intensity } \\
\text { index (\%) }\end{array}$ \\
\hline **North west farm lands & Arua, Nwoya and Amuru & 2.5 \\
Central woodland savannah & Mubende & 21.0 \\
The northern moist farm lands & Lira, Apac, Dokolo & 17.9 \\
South west grass farmland & Ntungamo, Rakai, Lwengo and Bukomansimbi & 7.8 \\
South western high lands & Kabale, Kisoro & 9.5 \\
Mt. Elgon farm lands & Mbale, Bulambuli & 17.8 \\
Lake Victoria crescent and Mbale & Masaka, Luwero & 29.0 \\
farm lands & & \\
\hline
\end{tabular}

** The NWF has a unimodal rainfall pattern and thus one season data was collected 
TABLE 2. Intensity of common bacterial blight in four rainfall zones in Uganda in averaged over two seasons of 2016

\begin{tabular}{llr}
\hline Rain fall range $\left(\mathrm{mm} \mathrm{year}^{-1}\right)$ & Representative districts & $\begin{array}{c}\text { Disease } \\
\text { intensity } \\
\text { index }(\%)\end{array}$ \\
\hline $410-1030$ & Arua, Ntungamo, Rakai, Lwengo and Bukomansimbi & 6.9 \\
$1000-1200$ & Mubende, Luwero, Apac, Masaka, Lira & 29.4 \\
$1200-1570$ & Amuru, Nwoya, Dokolo, Kisoro & 5.0 \\
$1570-1840$ & Mbale, Bulambuli & 17.8 \\
\hline
\end{tabular}

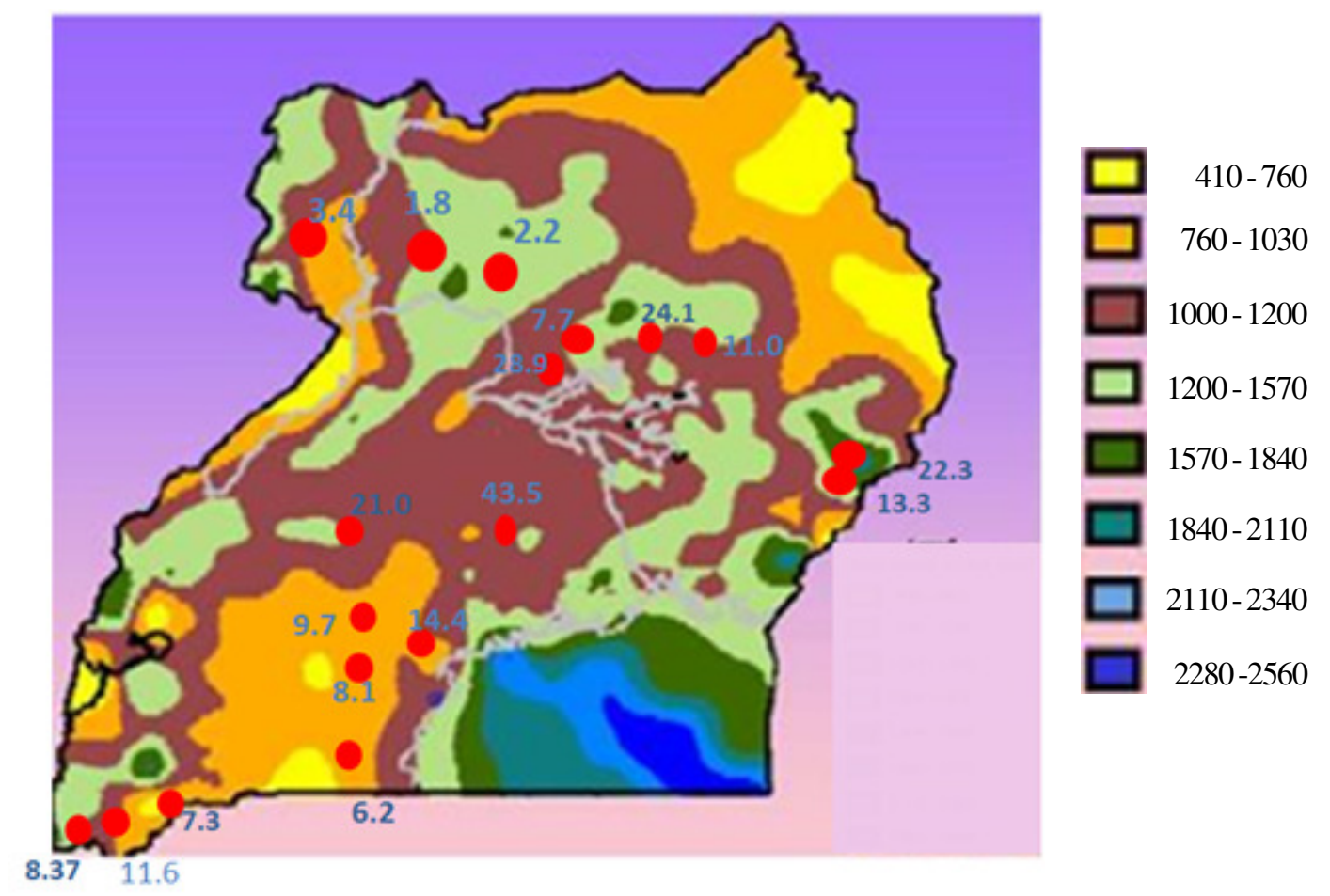

Figure 1. Map of disease intensity index (\%) of common bacterial blight of beans in relation to rainfallbased ecologies in Uganda average over two seasons of 2016. 
The disease incidences also varied significantly within and between altitudes. The low altitude areas (1000-1200 masl) recorded the highest CBB incidence at $26.5 \%$, mid altitude (1200-1500 masl) at $21.9 \%$ and high altitude $(>1500)$ at $17.2 \%$. On the other hand, the moderate disease severities were recorded in mid altitude areas at 2.5 on a scale of 1-5.

As expected, a negative relationship (Fig. 2) was observed between CBB intensities and the productivity of beans in the surveyed localities $(r=-0.51, \mathrm{P}<0.05)$. Areas with high productivity were associated with low $\mathrm{CBB}$ pressures. Yield losses due to $\mathrm{CBB}$ ranged from $20.24 \mathrm{~kg} \mathrm{ha}^{-1}$ in Northwest farm land agroecology, to $400.520 .24 \mathrm{kgha}^{-1}$ in the Victoria Crescent and Mbale farmland (Table 3).

Source and type of bean seed. Seed sources for the farmers were largely informal, with $96.2 \%$ of the farmers obtaining beans for planting from this source. It was observed that farmers rarely used certified seed from agrodealers, including seed companies. Only 3.8\% of the surveyed fields planted certified seed from agro-dealer. Majority (50.3\%) of the surveyed bean fields were planted using home saved (own) seed; closely followed by $43.2 \%$ of the fields planted using grain from the market (Table 4). It was also observed that there was regional specialisation in production of certain varieties. Central Uganda where the highest CBB intensity was reported, grew Nambale short, Nambale long and yellow varieties; while small black beans and Kaula variety were dominant in the north. The western region grew mainly Nambale short, Nambale long, yellow varieties and climbing varieties. Eastern Uganda grew mainly Watatwa (climbing), Mufumba chai (Bush) and Kanyebwa (Bush). The west Nile districts grew Medium white, K132, Bam, NABE, 14, 15 and 17 (Table 5).

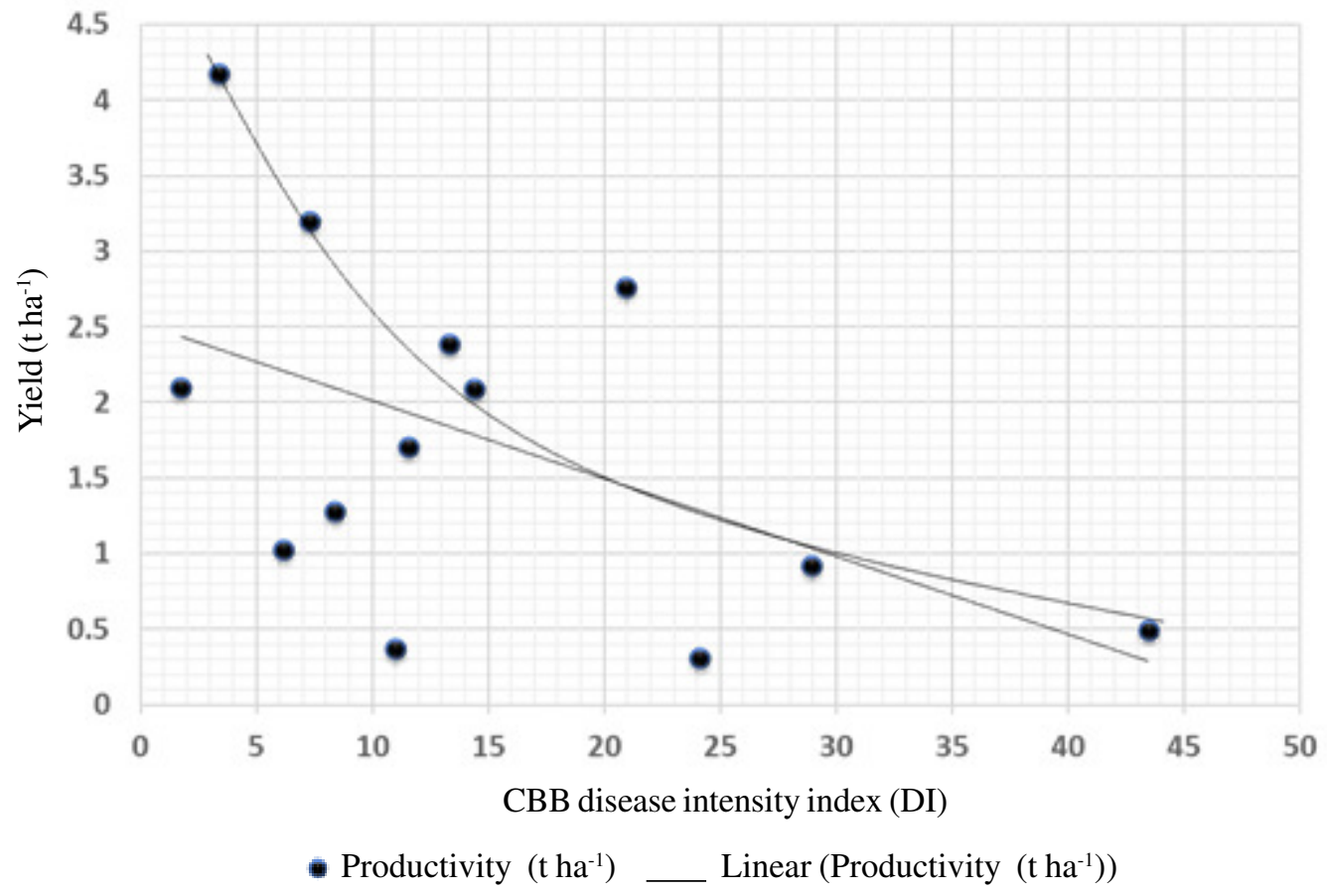

Figure 2. Relationship between bean productivity in selected locations and CBB pressure. 
TABLE 3. Comparison of Common bacterial blight disease intensity and estimated yield loss in surveyed localities of Uganda

\begin{tabular}{llcccc}
\hline District & $\begin{array}{c}\text { Agro-ecology } \\
\text { (Wartman,1999) }\end{array}$ & $\begin{array}{c}\text { Disease intensity } \\
\text { index }\left(\mathrm{D}_{\mathrm{I}}\right) \%\end{array}$ & $\begin{array}{c}\text { Average } \\
\text { productivity } \\
\left(\mathrm{kg} \mathrm{ha}^{-1}\right)\end{array}$ & $\begin{array}{c}\text { Estimated yield } \\
\text { loss }\left(\mathrm{kg} \mathrm{ha}^{-1}\right)\end{array}$ & CBB rating \\
\hline Arua & NWF & 3.38 & 4180 & 38.9 & Low \\
Nowoya & NWF & 2.19 & - & 26.1 & Low \\
Amuru & NWF & 1.76 & 2039 & 20.24 & Low \\
Apac & NMF & 28.93 & 920 & 332.7 & High \\
Dokolo & NMF & 10.97 & 370 & 126.2 & Moderate \\
Lira & NMF & 24.13 & 310 & 277.5 & Moderate \\
Mubende & CWS & 20.95 & 2760 & 240.9 & Moderate \\
Masaka & VC\&MF & 14.42 & 2090 & 164.7 & Moderate \\
Rakai & SWGF & 6.18 & 1030 & 71.07 & Low \\
Ntungamo & SWGF & 7.27 & 3200 & 83.60 & Low \\
Luwero & VC\&MF & 34.83 & 490 & 400.5 & High \\
Bukomansimbi & SWGF & 9.71 & - & 111.7 & Moderate \\
Mbale & EF & 13.3 & 2390 & 153.0 & Moderate \\
Bulambuli & EF & 22.3 & - & 256.5 & Moderate \\
Kisoro & SW & 8.37 & 1280 & 96.3 & Low \\
Kabale & SW & 11.57 & 1710 & 133.1 & Moderate \\
\hline
\end{tabular}

$\mathrm{NWF}=$ Northwest farm land, $\mathrm{NMF}=$ Northern moist farm land, $\mathrm{CWS}=$ Central woodland savannah, $\mathrm{VC}$ and $\mathrm{MF}=$ Victoria Cresent and Mbale farm land, $\mathrm{SWGF}=$ South west grass farm land, EF = Elgon Farm land, SW = South west high land.

TABLE 4. Farmer's bean seed sources in Uganda as of 2016(a)

\begin{tabular}{lcc}
\hline Seed source & Number of farmers & Farmers using the source $(\%)$ \\
\hline Agro dealer & 7 & 3.8 \\
Fellow farmers & 5 & 2.7 \\
Market & 79 & 43.2 \\
Own seed & 92 & 50.3 \\
Total & 183 & 100 \\
\hline
\end{tabular}

\section{DISCUSSION}

Distribution of common bacterial blight disease. Beans showing CBB symptoms were widely distributed across all agroecologies.While Wortman et al. (1998) reported the relative importance of $\mathrm{CBB}$ to be low in highland areas of Uganda (south- western high lands and Elgon), and high in mid-altitude zones characterised by tall and short grass (north central, northwest, western, eastern, and central). With few exceptions in north-western and eastern Uganda, the relative distribution and importance of CBB situation has not significantly changed. The North west tall grass zone was found to have low disease 
pressure in this study; while the Mt. Elgon farm land agro-ecology registered unexpectedly high CBB intensity (Table 2).

Though CBB disease is known to be highly influenced by the rainfall, it was to the contrary in this study. Traditionally wet areas of the northwest tall grass zone (Amuru and Nwoya), recorded the lowest $\mathrm{CBB}$ intensities in the country. The exceptions could be reflecting climatic changes where traditionally humid areas are becoming less humid and slightly warmer ( USAID, 2013; FEWS-NET, 2012). Majaliwa et al. (2015) reported declining rainfall trends in North west farm land agroecology (Climatologically Homogenous rainfall zones J \& K) where Arua, Amuru and Nwoya fall. The low disease intensities in Amuru and Nwoya thus, partly attributed to declining rainfall trends, long farrow periods and the savannah type of vegetation. Bamkefa et al. (2011) reported a decreased intensity of CBB of cassava in low land humid savannah zones. Rainfall variability across locations and seasons could as well explain the differences observed in CBB intensity.

While the country received near normal rainfall in the months of April and May preceding the first season survey (Fig. $3 \mathrm{~A}$ ), in second season the rainfall received in the month prior to survey (August and September) were less than normal rainfall. The average temperatures were generally lower in the second season when compared with the first season of 2016 (Fig. 3B). Common bacterial blight disease is known to be favoured by high temperatures and high humidity (Akhavan $e t$ al., 2013), which were more apparent in the first season. It is reported that under low humidity and high temperatures, the bean plants may remain asymptomatic throughout the season (Dos Anjos Marquez and Samson, 2016). This possibly explains why disease intensity was lower in second season compared to first season. Previously, Sengoba (1985) reported that CBB in Uganda was more prevalent and severe during the second rainy season. This was so because the first season rains were normally shorter than the second 
A Rainfall (mm) trends in Uganda 2015-2016
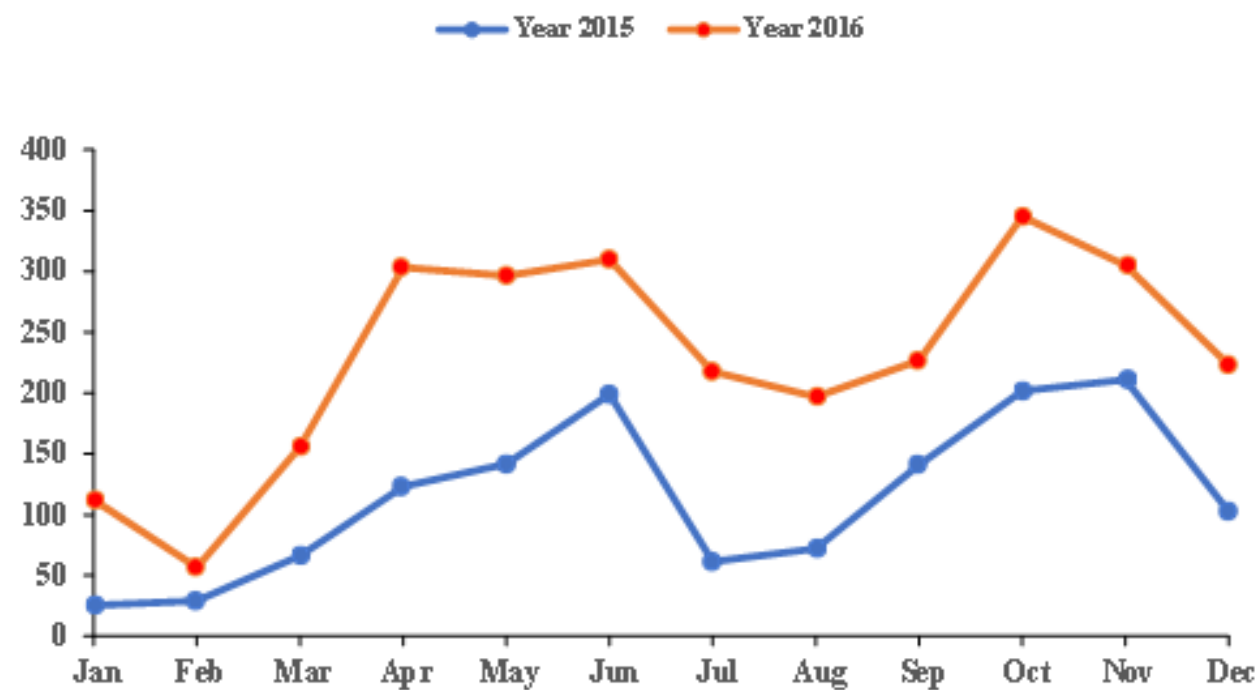

B Temperature $\left({ }^{\circ} \mathrm{C}\right)$ trends in Uganda 2016
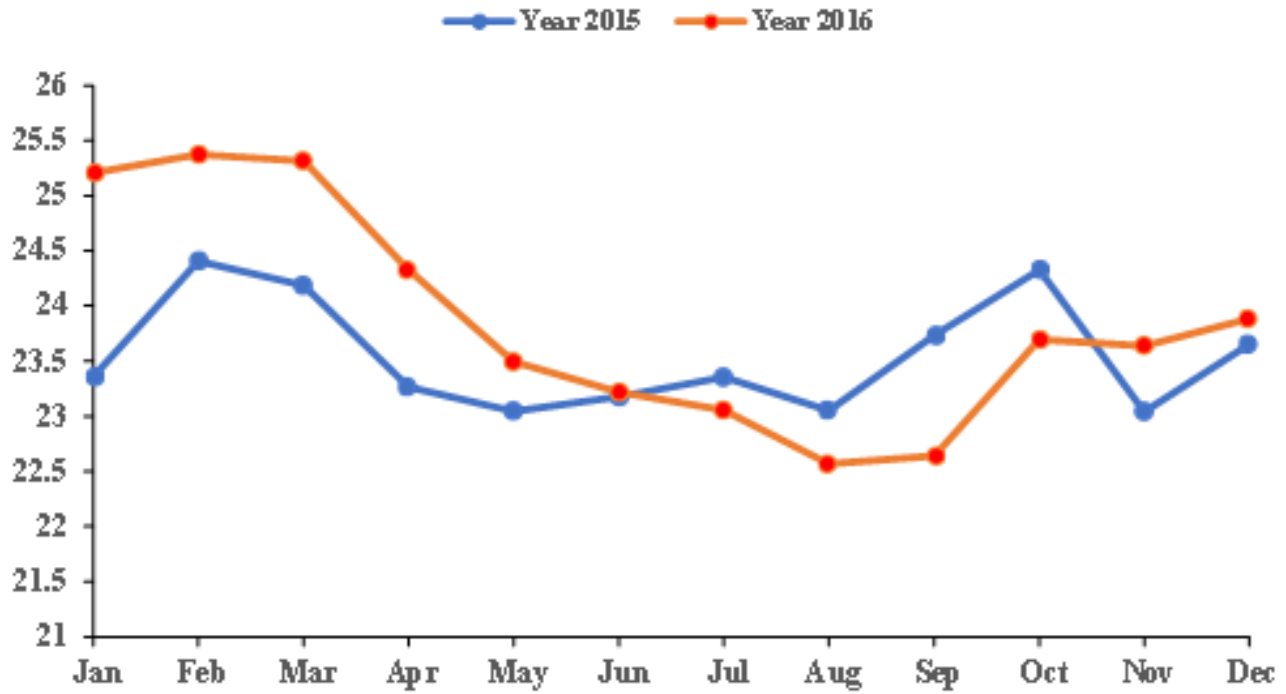

Figure 3. Weather trends across all regions of Uganda in $2016 \mathrm{~A}=$ Rainfall $(\mathrm{mm})$ and $\mathrm{B}=$ Temperature $\left({ }^{\circ} \mathrm{C}\right)$.

season rains, but this was the opposite in 2016 . It is, thus possible that areas and seasons that were previously wet and cool in second season are becoming less wet and warmer. The variation in symptoms observed could be due to differences in varieties, site specific conditions or new species of bacteria that cause CBB like symptoms.

Distribution of common bacterial blight disease and seed sources. The distribution of $\mathrm{CBB}$ within and between regions was 
variable (Fig. 1). This variability in disease distribution could be attributed to variable quality and health status of seeds planted. This explains why fields in close proximity in Mbale and Bulambuli were found with contrasting CBB incidences and severities. It was observed that a farmer can plant the same bean garden with seed from different sources. In a related study, Damulira et al. (2014) while working on seed transmitted Angular leaf spot, also reported variable incidences in the districts studied in Uganda.

Seed is reported to be the primary means by which CBB is spread (Karavina, 2011; Akhavan et al., 2013). Continuous cropping by farmers and recycling of seed contribute to high bean disease pressure and subsequently to low yields. In this study, CBB explained $26.1 \%$ of the observed difference in bean productivity in the different districts in Uganda. This shows that the disease has a great influence on bean productivity. Work done by Opio et al. (1992) showed that for each $1 \%$ increase in the incidence of common blight during reproductive growth, there is a yield loss of $3.5-11.5 \mathrm{~kg} \mathrm{ha}^{-1}$, depending on the season. Due to the limited number of farmers that were using certified seed, we could not meaningfully compare CBB pressure in fields planted with seed from informal and formal sources.

However, in a related study in Eastern Kenya, Kosogei (2016) reported higher inoculum levels of Xanthomonas axonopodis pv. phaseoli and Pseudomonas savastanoi pv. phaseolicola on farm saved and market sourced seeds, compared to certified seeds; and this was also reflected in yields obtained from the two sources. This, therefore, shows that the use of good quality seed would minimise the impact of CBB. In Uganda, certified bean seed is rarely used due to chronic shortage and limited access to the seed (Monyo and Gowda, 2014). In some cases, a bean field is planted with bean seed from different sources, in order to cover up to the required amount. The near absence of agrodealers as a seed source for legumes has also been reported in other African countries like Kenya and DRC (McGuire and Sperling, 2016). Frequent bean crop failure due to bean diseases and other constraints like drought, also contribute to farmer's use of seed from variable sources. It was also noted that in a season following bean crop failure, the farmers normally purchase grain for planting. This puts them at risk of introducing new CBB strains into their gardens that may otherwise be disease free.

\section{CONCLUSION}

With few exceptions in north western Uganda and Eastern, the relative distribution and importance of $\mathrm{CBB}$ situation has not significantly changed from what was reported by Wortman in 1998. The few exceptions could be reflecting climatic changes where traditionally moist areas are becoming less humid and slightly warmer. The potential impact of climatic change on bacterial diseases of beans needs further investigation. The variations in CBB distribution between and within locations can largely be attributed to differences in quality of seed planted which varies from farmer to farmer depending on the source. Farmer's agronomic practices like crop rotation, time of planting and sorting of seed before planting should be investigated as these too contribute to variation in disease distribution. Since sourcing of bean seed remains largely informal, both formal and informal seed sources should be supported. Areas like Amuru, Nwoya, Arua and Ntungamo that recorded low CBB pressure could be recommended for commercial certified bean seed production, especially the bush bean type while community seed production initiatives can be technically backstopped by research and government. 


\section{ACKNOWLEDGEMENT}

The authors are grateful for research funds from Higher Education, Science and Technology (HEST) project through International Centre for Tropical Agriculture (CIAT) (Uganda). We thank the bean staff and personnel at CIAT, Kawanda for all assistance offered.

\section{REFERENCES}

Akhavan, A., Bahar, M., Askarian, H., Lak, M.R., Nazemi, A. and Zamani, Z. 2013. Bean common bacterial blight: Pathogen epiphytic life and effect of irrigation practices. SpringerPlus 2(1):41.

Bamkefa, B.A., Bah, E.S. and Dixon, A.G.O. 2011. Survey of the current distribution and status of bacterial blight and fungal diseases of cassava in Guinea. African Journal of Root and Tuber Crops 9(1):1-5.

Basalirwa, C.P.K. 1995. Delineation of Uganda into climatological rainfall zones using the method of principal component analysis. International. Journal on Climate 15:11611177.

Benjarano-Alcazar, J., Blanco-Lopez, M.A., Melero-Vara, J.M. and Himenez-Diaz, R.M.1996. Etiology,importance and distribution of verticillium wilt of cotton in Southern Spain. Plant Disease 80:12331238

Buruchara, R., Chirwa, R., Sperling, L., Mukankusi, C., Rubyogo, J.C., Muthoni, R. and Abang, M.M. 2011. Development and delivery of bean research varieties in Africa: The Pan-Africa bean research alliance (PABRA) model. African Crop Science Journal 19:227 - 245.

Ddamulira, G., Mukankus, C., OchwoSsemakula, M., Edema, R., Sseruwag, P. and Gepts, P. 2014. Distribution and Variability of Pseudocercospora griseola in Uganda. Journal of Agricultural Science, 6(6):16-29. http://www.ccsenet.org/ journal/index.php/jas/article/view/33535.
Dos Anjos Marques, A.S. and Samson, R. 2016. Population dynamics of Pseudomonas savastanoi pv. phaseolicola in bean, throughout the epiphytic and pathogenic phases. Pesquisa Agropecuaria Brasileira 51(5):623-630.

FEWS-NET, 2012. A climate trend analysis of Uganda. Fact Sheet 2012. http:// earlywarning.usgs.gov/fews/reports. php.

Karavina, C., Mandumbu, R., Parwada, C. and Tibugari, H. 2011. A review of the occurrence, biology and management of common bacterial blight. Journal of Agricultural Technology 7(6):1459-1474. http://digilib.buse.ac.zw:8090/xmlui/handle/ $123456789 / 129$.

Kosgei, J.B. 2016. Effect of seed quality and soil borne pathogen inoculum on disease pressure in common bean. Msc. Thesis University of Nairobi, Nairobi, Kenya 119pp.

Majaliwa J.G.M, Tenywa, M.M. and Bamanya D.M.W. 2015. Characterization of historical seasonal and annual rainfall and temperature trends in selected climatological homogenous rainfall zones of Uganda. Global Journal of Science Frontier Research 15(4):1-21.

McGuire, S. and Sperling, L. 2016. Seed systems smallholder farmers use. Food Security 8(1):179-195.

Monyo, E.S. and Gowda, C.L.L. 2014. Grain legumes strategies and seed roadmaps for select countries in Sub-Saharan Africa and South Asia: Tropical Legumes II project report, ICRISAT. pp.1-284.

Opio, A.F., Teri, J.M. and Allen, D.J. 1992. Assessment of yield losses caused by common bacterial blight of beans in Uganda. Annual Report. Pub. National Agricultural Library Digital Collections of USDA, USA.

Opio, A.F., Allen, J.J. and Teri, J.M. 1996. Pathogenic variation in Xanthomonas campestris pv. phaseoli the causal agent of common bacterial blight in phaseolus bean. Plant Pathology 45:126-1133. 
USAID, 2013. Uganda Climatic change vulnerability assessment Report, Annex A-

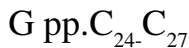

Sengoba, T.N. 1985. The incidence and severity of the major bean diseases of Uganda. Annual Report. Pub. National Agricultural Library Digital Collections of USDA.
Wortman, C.S., Kirkby, R.A., Eledu, C.A. and Allen, D.J. 1998. Atlas of common bean (Phaseolus vulgaris L.) production in Africa. CIAT, ISBN: 9589439942. 133pp Wortman, C.S. and Eledu, C.A. 1999. Uganda's Ecological Zones. A guide for Planners and Policy Makers. Kampala Uganda, CIAT. pp. 1-54. 